WEBв, M. (1951). J. gen. Microbiol. 5, 485-495.

\title{
The Influence of Magnesium on Cell Division
}

\section{The Effect of Magnesium on the Growth of Bacteria in Chemically-Defined Media of Varying Complexity}

\author{
By M. WEBB
}

The Strangeways Research Laboratory, Cambridge

\begin{abstract}
SUMMARY: The growth of bacteria in chemically-defined media containing mixtures of amino-acids is less dependent upon the magnesium concentration than in simple media composed of salts, glucose or glycerol and a single source of nitrogen. In the more complex chemically-defined media growth initially increases rapidly with, and then becomes independent of, the magnesium concentration. Gram-positive bacilli fail to grow when the magnesium content of the medium is less than 0.66 p.p.m., whereas this amount of magnesium is almost sufficient to maintain maximum growth of the Gram-negative bacteria. In addition, a deficiency of magnesium (i.e. c. 1-5 p.p.m.) inhibits the cell division of the Gram-positive rod-shaped organisms, and results in the formation of filamentous cells.
\end{abstract}

The importance of ionic magnesium in the processes of bacterial growth and cell division has been recorded in previous papers (Webb, 1948, 1949a, b, 1951). In peptone media, a deficiency of magnesium predominantly inhibits the cell division of Gram-positive rods and results in the formation of filamentous cells. In simple chemically-defined media, however, the growth of bacteria is a function of the magnesium concentration, and in such media containing suboptimal amounts of magnesium, filamentous cells are not observed.

To explain these differences it was suggested (Webb, 1949b) that magnesium is essential both for the synthesis of intermediate metabolites and for cell division. In complex media which already contain some or all of the intermediate metabolites, the synthetic activities of the cell are decreased and a deficiency of magnesium inhibits cell division. However, in simple chemicallydefined media, where synthesis precedes cell division, a deficiency of magnesium inhibits growth and normal cell division occurs throughout the restricted population that the medium is able to maintain.

Evidence in favour of the above hypothesis is provided by the present communication which records the results of an investigation of the effect of magnesium on the growth of bacteria in more complex chemically-defined media containing amino-acids and other growth factors. Under these conditions, the growth of bacteria is less dependent upon the magnesium concentration, and a deficiency of magnesium primarily inhibits the cell division of the Grampositive rods.

\section{MATERIALS AND METHODS}

It was found in early experiments that in media containing several aminoacids but no added magnesium, the cumulative effect of traces of magnesium in the commercial amino-acids used was sufficient to maintain the growth of bacteria for an indefinite number of subcultures. Similar results were obtained after treatment of concentrated solutions of the amino-acids at $\mathrm{pH} 9$ with 
8-hydroxyquinoline according to the method of Waring \& Werkman (1942); the magnesium content of the media was then of the order of 1-2 p.p.m. when estimated by comparative methods using Titan yellow. Media 'biologicallyfree' from magnesium were finally obtained by a modification of the method of Nicholas (1951, and personal communication).

Pyrex glassware, used throughout, was cleaned in concentrated chromicsulphuric acid mixture rinsed in distilled water, $0.1 \mathrm{M}$ sodium bicarbonate (Analar) in glass-distilled water, $0 \cdot 1 \mathrm{~N}$ nitric acid (redistilled) in double-distilled water, and washed in six changes of double-distilled water. The glassware was dried at $180^{\circ}$ in Pyrex containers. Spatulas and Pasteur pipettes were made from Pyrex glass rod and tubing, respectively, cleaned as above.

A concentrated solution of the nutrient substances, other than glucose, phosphate and the micro-nutrients, in double-distilled water, was adjusted to pH 9 with ammonium hydroxide (prepared by collecting ammonia in doubledistilled water) and $5 \mathrm{ml}$. of a $2 \%(\mathrm{w} / \mathrm{v})$ solution of 8-hydroxyquinoline in $2 \mathrm{~N}$ acetic acid (Analar) added. After $24 \mathrm{hr}$. at $37^{\circ}$ the solution was filtered through Whatman no. 5 filter-paper, and the filtrate extracted six times with redistilled chloroform to remove excess 8-hydroxyquinoline and then six times with redistilled ether to remove residual chloroform. Micro-nutrients $\left(\mathrm{Fe}^{+++}\right.$, $\mathrm{Cu}^{++}$, as required) and glucose were added, the solution diluted to volume with double-distilled water, adjusted to $\mathrm{pH} 6.5$ with a standard solution of constant boiling hydrochloric acid in double-distilled water and sterilized by steaming.

As glucose was decomposed with the formation of toxic products at the alkaline $\mathrm{pH}$ used in the above purification, trace metals were removed from a concentrated solution of the sugar by a column of ion exchange resin (Zeo-karb 215). The column was prepared as follows:

A suspension of Zeo-karb 215 in $\mathbf{0 . 1} \mathrm{N}$ hydrochloric acid (concentrated hydrochloric acid distilled in a Pyrex still, and the constant-boiling distillate diluted with double-distilled water) was introduced into a Pyrex glass tube $(30 \times 1 \mathrm{~cm}$.) cleaned in the usual way, and containing a plug of filter-paper previously extracted with $0 \cdot 1 \mathrm{~N}$ hydrochloric acid, at a constriction $4 \mathrm{~cm}$. from the lower end. The column was washed with double-distilled water $(500 \mathrm{ml}$.), and then a solution of glucose $(25 \mathrm{~g}$.) in double-distilled water $(250 \mathrm{ml}$.) allowed to run slowly through the resin. The first $50 \mathrm{ml}$. of effluent were discarded; the remainder, containing the bulk of the glucose, was adjusted to $c . \mathrm{pH} 6 \cdot 0$ with ammonium hydroxide and sterilized. Analyses for reducing sugar by the method of Shaffer \& Hartman (1920) showed that no loss of glucose occurred. Control experiments, in which glucose solutions containing varying concentrations of magnesium sulphate were passed through such columns and then analysed qualitatively with Titan yellow, showed that the magnesium was removed completely.

Phosphate solutions adjusted to $\mathrm{pH} 6.5$ with ammonium hydroxide, were sterilized separately in steam and added to the main bulk of the medium when cold. The potassium dihydrogen phosphate (Analar) used was recrystallized four times from a mixture of double-distilled water and twice-distilled ethanol, and dried at $80^{\circ}$. 


\section{EXPERIMENTAL \\ Influence of magnesium on bacterial growth in complex chemically-defined media}

Preparation of inoculum. The technique used to obtain inocula free from magnesium was as previously described (Webb, 1949b). Subcultures were made from stock into the chemically defined media and incubated for $\mathbf{4 8} \mathrm{hr}$. Serial subcultures were then made into the same medium every $48 \mathrm{hr}$. until the final subculture failed to grow. The penultimate culture was used as inoculum. It was necessary to subculture Gram-negative bacteria about six times before growth ceased, whereas two or three subcultures sufficed for the Gram-positive organisms (Table 1). These results already indicate a difference in the magnesium requirements of these two types of organisms.

Table 1. Relative amounts of growth in serial subcultures of Gram-positive and Gram-negative organisms in Heigener's (1935) medium, free from magnesium

Growth (Spekker reading) after $48 \mathrm{hr}$. at $37^{\circ}$

$\begin{array}{ccccccc}\begin{array}{c}\text { Subculture } \\ \text { no. }\end{array} & \begin{array}{c}\text { Serratia } \\ \text { marcescens }\end{array} & \begin{array}{c}\text { Aerobacter } \\ \text { aerogenes }\end{array} & \begin{array}{c}\text { Aerobacter } \\ \text { cloacae }\end{array} & \begin{array}{c}\text { Bacillus } \\ \text { mesentericus }\end{array} & \begin{array}{c}\text { Bacillus } \\ \text { mycoides }\end{array} & \begin{array}{c}\text { B. subtilis } \\ \text { var. viscosus }\end{array} \\ 1 & 0 \cdot 352 & 0.333 & 0.340 & 0.098 & 0.075 & 0.076 \\ 2 & 0.283 & 0.212 & 0.272 & 0.032 & 0.040 & 0.049 \\ 3 & 0.212 & 0.193 & 0.218 & 0.000 & 0.000 & 0.002 \\ 4 & 0.003 & 0.154 & 0.075 & - & - & - \\ 5 & - & 0.080 & 0.005 & - & - & - \\ 6 & - & 0.003 & 0.000 & - & - & -\end{array}$

An increase in polysaccharide synthesis was observed in the serial subcultures of the organisms listed in Table 1. This effect of magnesium deficiency was particularly marked with the Gram-negative organisms; cultures of Pseudomonas aeruginosa, for example, became so viscous that the growth could not be measured turbidimetrically.

Chemically-defined media. The media used (Table 2) varied from a simple mixture of four amino-acids, pyruvic acid, nicotinic acid and mineral salts (medium 1) to the complex solutions required for the nutrition of the lactobacilli, streptococci, Kurthia zenkeri (medium 4) and Clostridium welchii (medium 5). The influence of magnesium on the growth of various Grampositive organisms in these nutrient solutions is shown in Figs. $\mathbf{1}$ and $\mathbf{2}$ and Table 3 . When these results are compared with those previously obtained with the same organisms grown in simple chemically-defined media (Webb, 1949b), it is apparent that the growth of Gram-positive bacteria in the presence of amino-acids and other growth factors is much less dependent upon the magnesium concentration of the medium (cf. Fig. 5 and also Figs. 1 and 2 of the preceding paper (Webb, 1951)).

Growth of the lactobacilli and streptococci in medium 4 (Fig. 2) occurred at zero magnesium concentration, since this medium contained a low concentration of manganese (2 p.p.m.), and, as previously shown (Webb, 1951), this metal can partially replace magnesium in bacterial growth and cell division. 
Table 2. The organic composition of the chemically-defined media used

(Composition: quantities shown per $100 \mathrm{ml}$. medium.)

Medium 1. L-Asparagine, L-cysteine $\mathbf{H C l}$, L-glutamic acid and L-arginine $\mathbf{H C l}$ (50 mg.), nicotinic acid (1 mg.), pyruvic acid (0.5 g.)

Medium 2. (Heigener, 1935.) DL-Valine (0.234 g.), glycine (0.150 g.), DL-alanine (0.178 g.), DL-phenylalanine (0.33 g.), DL-leucine (0.262 g.), L-asparagine (0.264 g.), Lglutamic acid $(0 \cdot 294 \mathrm{~g}$.$) , glucose (0.250 g.)$

Medium 3. (Glinka-Tschernorutzky, 1933.) Glycine (50 mg.), DL-valine (50 mg.), DL-alanine (50 mg.), DL-phenylalanine (50 mg.), DL-leucine (50 mg.), L-glutamic acid (50 mg.), DL-aspartic acid (50 mg.), L-arginine (50 mg.), L-cystine (25 mg.), L-tryptophan (25 mg.), DL-tyrosine (25 mg.), L-proline (25 mg.), L-histidine HCl (25 mg.), DL-lysine $\mathrm{HCl}$ (25 mg.), DL-serine (25 mg.), glucose (0.5 g.)

Medium 4. (Krueger \& Peterson, 1945, modified.) Amino-acid mixture as in medium 3, with addition of $\mathrm{DL}$-isoleucine (25 $\mathrm{mg}$.), DL-norleucine $(25 \mathrm{mg}$.), DL-threonine (25 mg.), DL-methionine (25 mg.), L-cysteine HCl (5 mg.), adenine sulphate (3.0 mg.), guanine hydrochloride (2.0 mg.), riboflavin (25 $\mu \mathrm{g}$.$) , calcium-D-$ pantothenate $(50 \mu \mathrm{g}$.$) , nicotinic acid (250 \mu \mathrm{g}$.$) , pyridoxin hydrochloride$ (50 $\mu \mathrm{g}$.), $p$-aminobenzoic acid (25 $\mu \mathrm{g}$.), aneurin (5 $\mu \mathrm{g}$.$) , biotin (0.001 \mu \mathrm{g}$.), folic acid (0.001 $\mu \mathrm{g}$.$) , sodium acetate (0.6 g.), glucose (1.0 g.)$

Medium 5. (Boyd, Logan \& Tytell, 1948, modified.) Amino-acid mixture as in medium 3 with omission of DL-alanine and DL-lysine, and addition of DL-methionine (5 mg.), L-cysteine HCl (5 mg.), adenine sulphate (3 mg.), guanine hydrochloride (2.0 mg.), uracil (1.7 mg.), biotin (0.05 $\mu \mathrm{g}$.), calcium-D-pantothenate (100 $\mu \mathrm{g}$.$) ,$ pyridoxin (50 $\mu \mathrm{g}$.$) , riboflavin (50 \mu \mathrm{g}$.$) , ascorbic acid (25 \mathrm{mg}$.$) , glucose (0.5 g.),$ ammonium lactate (0.5 g.).

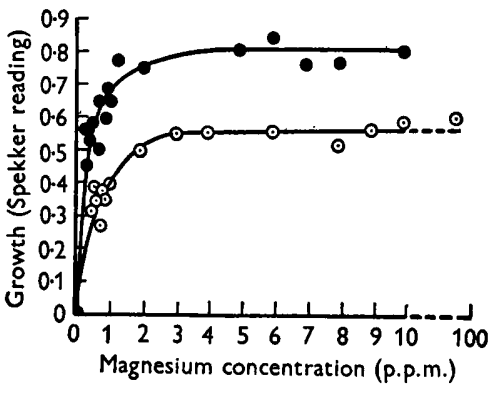

Fig. 1

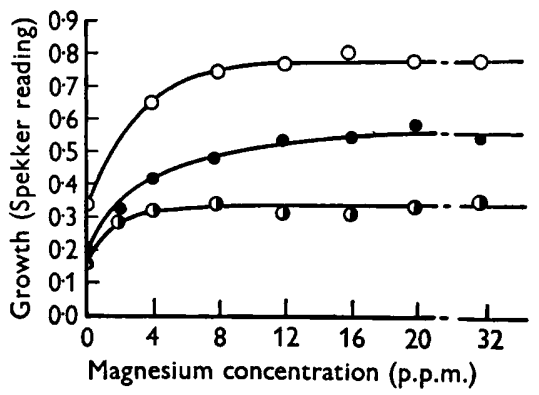

Fig. 2

Fig. 1. The influence of magnesium on the growth of Bacillus vulgatus (O-O) and B. mycoides $(\odot-\odot)$ in Glinka-Tschernorutzky (1933) medium (medium 3, Table 2). Growth measured turbidimetrically after $72 \mathrm{hr}$. at $37^{\circ}$.

Fig. 2. The influence of magnesium on the growth of $\boldsymbol{L b}$. casei $\left(\mathrm{O}_{-} \mathrm{O}\right)$, Strep. pyogenes (-O) and Strep. faecalis (O-O) in medium 4, Table 2 containing 2 p.p.m. $\mathrm{Mn}^{++}$. Growth measured turbidimetrically after $80 \mathrm{hr}$. at $37^{\circ}$. Growth curves similar to the above were obtained with $L b$. delbrueckii and $K$. zenkeri and are not shown in the figure.

Although no growth occurred in the complete absence of magnesium and manganese (Figs. 1, 2; Table 3), maximum growth was attained when the magnesium concentration of the medium was $2-3$ p.p.m. Above this value the amount of growth was independent of further increases in the magnesium concentration (up to 100 p.p.m.). These results contrast with those obtained 
with simple chemically-defined media containing only salts, glucose or glycerol and a suitable source of nitrogen (Webb, 1949 b) where concentrations of magnesium much above the optimal inhibited the growth of a number of species of bacteria. It appears that in the complex chemically-defined media the presence of the amino-acids decreases the inhibitory or toxic effect of magnesium ions.

Table 3. Effect of magnesium concentration on the growth of Bacillus polymyxa, B. subtilis and Clostridium welchii in chemically-defined media

Magnesium
concentration
(p.p.m.)
$\mathbf{0} \cdot \mathbf{0}$
$\mathbf{1} \cdot 0$
$\mathbf{2} \cdot \mathbf{0}$
$\mathbf{3 \cdot 0}$
$\mathbf{4} \cdot \mathbf{0}$
$\mathbf{5 \cdot 0}$
$\mathbf{6} \cdot 0$
$\mathbf{7} \cdot 0$
$\mathbf{8} \cdot 0$
$\mathbf{9} \cdot 0$
$\mathbf{1 0} \cdot \mathbf{0}$

\begin{tabular}{ccc}
\multicolumn{3}{c}{ Relative growth } \\
B. polymyxa* & B. subtilis* & Cl. welchii $\uparrow$ \\
$0 \cdot 00$ & $0 \cdot 00$ & $0 \cdot 00$ \\
0.575 & $0 \cdot 289$ & $0 \cdot 350$ \\
$0 \cdot 610$ & $0 \cdot 320$ & $0 \cdot 372$ \\
$0 \cdot 630$ & $0 \cdot 350$ & $0 \cdot 405$ \\
$0 \cdot 649$ & $0 \cdot 350$ & $0 \cdot 335$ \\
$0 \cdot 592$ & $0 \cdot 358$ & $0 \cdot 373$ \\
$0 \cdot 620$ & $0 \cdot 332$ & $0 \cdot 375$ \\
$0 \cdot 600$ & $0 \cdot 352$ & $0 \cdot 374$ \\
$0 \cdot 628$ & $0 \cdot 356$ & $0 \cdot 365$ \\
$0 \cdot 608$ & 0.361 & $0 \cdot 385$ \\
0.622 & $0 \cdot 331$ & $0 \cdot 370$
\end{tabular}

* Growth measured turbidimetrically (Spekker absorptiometer) after $48 \mathrm{hr}$. at $37^{\circ}$ in medium 1 (Table 2).

$\dagger$ Growth (in medium 5, Table 2) measured turbidimetrically after $24 \mathrm{hr}$. at $37^{\circ}$ in an atmosphere of hydrogen.

A closer study was made with both Gram-positive and Gram-negative organisms at very low concentrations of magnesium (0-1.8 and 0-0.8 p.p.m. respectively). No growth of the Gram-positive organisms occurred when the magnesium concentration of the medium was less than 0.66 p.p.m. (Fig. 3), whereas this concentration was almost sufficient to maintain the maximum growth of the Gram-negative bacteria (Fig. 4). These results (Figs. 3, 4), however, show also that in addition to magnesium, the organic constituents of the medium influence the growth of the various bacteria, and suggest that the true influence of magnesium on bacterial growth under these conditions can be determined only when each organism is grown in a medium defined to suit its own nutritional requirements.

It was observed that growth occurred initially in the culture containing the highest concentration of magnesium. This effect of magnesium on the lag phase of the growth of Bacillus mycoides in medium 1 is shown in Table 4. The turbidimetric measurements recorded in Table 4 were made on growing cultures, wooden adaptors being constructed to hold the test-tubes in the cell mount of the Spekker absorptiometer. In consequence, although the tubes selected for the cultures appeared uniform, it is probable that the results of Table 4 represent a qualitative, rather than quantitative, expression of the amount of growth. 
The influence of magnesium concentration on morphology

Gram-positive bacteria. Filamentous cells (Pl. 1, figs. 1-3) were observed consistently in stained smears prepared throughout the serial subcultures of the Gram-positive rods recorded in Table 1 , and in the assay tubes containing the lower magnesium concentrations (Figs. 1, 2; Table 3). Organisms grown in

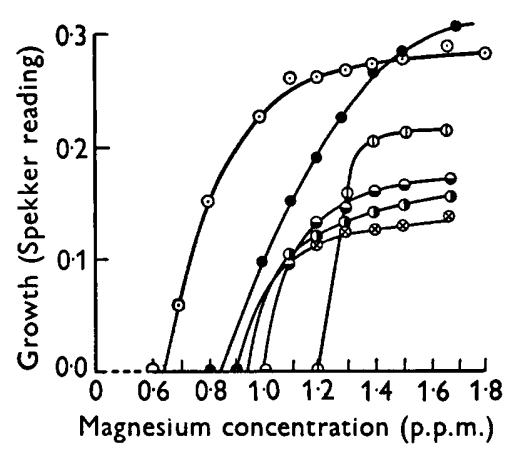

Fig. 3

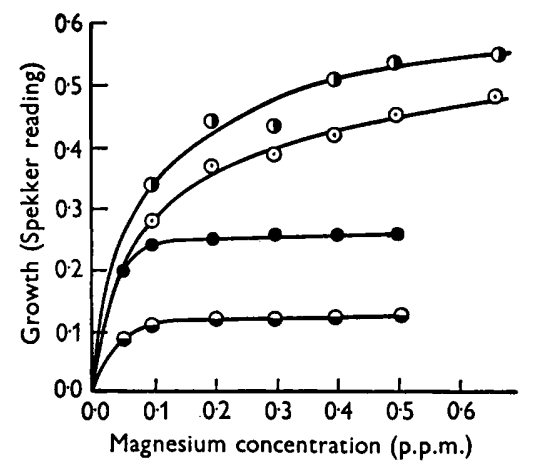

Fig. 4

Fig. 3. The influence of low concentrations of magnesium on the growth of certain Grampositive bacilli. $\boldsymbol{B}$. subtilis var. viscosus $(\odot-\odot), \boldsymbol{B}$. mesentericus ((1)-(1)), and $B$. mycoides $(\ominus \ldots-\circlearrowright)$ grown in medium 1 , Table $2 ; B$. subtilis var. viscosus $(\otimes-\otimes)$, B. mesentericus $(\Theta-\bigcirc)$ and B. mycoides $(-\bigcirc)$ grown in medium 2, Table 2. Growth measured turbidimetrically after $72 \mathrm{hr}$. at $37^{\circ}$.

Fig. 4. The influence of low concentrations of magnesium on the growth of certain Gramnegative bacteria. A. aerogenes $(\odot-\bigcirc)$, and $A$. cloacae $(\odot-\odot)$ in medium 2, Table 2. A. aerogenes ( $-\bigcirc)$ and Serratia marcescens $\left(\Theta_{-}\right)$) in medium 1 , Table 2. Growth measured turbidimetrically after $72 \mathrm{hr}$. at $37^{\circ}$.

Table 4. Effect of magnesium concentration on the lag phase of the growth of Bacillus mycoides in medium 1 (Table 2) at $37^{\circ}$

\begin{tabular}{|c|c|c|c|c|}
\hline & \multicolumn{4}{|c|}{ Magnesium concentration (p.p.m.) } \\
\hline & $1 \cdot 1$ & $\mathbf{1} \cdot \mathbf{2}$ & $1 \cdot 3$ & $1 \cdot 4$ \\
\hline Time & \multicolumn{4}{|c|}{ Relative growth (Spekker reading) } \\
\hline $\mathbf{0}$ & 0.000 & 0.000 & 0.000 & 0.000 \\
\hline 12 & 0.000 & 0.000 & 0.000 & 0.090 \\
\hline 24 & 0.000 & $0 \cdot 040$ & $0 \cdot 101$ & $0 \cdot 134$ \\
\hline 36 & $0 \cdot 000$ & $0 \cdot 090$ & $0 \cdot 101$ & $0 \cdot 160$ \\
\hline 48 & $0 \cdot 000$ & $0 \cdot 101$ & $0 \cdot 144$ & $0 \cdot 170$ \\
\hline 72 & 0.095 & $0 \cdot 138$ & $0 \cdot 148$ & $0 \cdot 164$ \\
\hline
\end{tabular}

Glinka-Tschernorutzky's (1933) complex medium (medium 3, Table 2; Fig. 1) under conditions of magnesium deficiency, formed extremely long filaments, many of which extended over several fields of the microscope (Pl. 1, figs. 4, 5).

With increasing concentrations of magnesium there was a gradual change in the morphology of the cells, roughly as follows: 


\begin{tabular}{|c|c|c|c|c|c|}
\hline Morphology: & Filaments - & $\begin{array}{l}\text { Shorter } \\
\text { filaments }\end{array}$ & 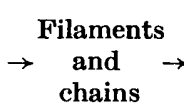 & $\begin{array}{l}\text { Chains and } \\
\text { 'normal' } \\
\text { rods }\end{array}$ & $\rightarrow \begin{array}{c}\text { Isolated } \\
\text { 'normal' } \\
\text { rods }\end{array}$ \\
\hline $\begin{array}{l}\text { Magnesium } \\
\text { concentra- } \\
\text { tion (p.p.m.) }\end{array}$ & $\mathbf{0}$ & 10 & 12 & $\mathbf{2 4}$ & $\begin{array}{l}28 \text { and } \\
\text { greater }\end{array}$ \\
\hline
\end{tabular}

The above values are approximate only, and considerable overlapping of these limits occurred in many experiments. However, it may be of some significance that an abrupt transition from filaments to 'normal' rods was not observed.

Filament formation occurred also in magnesium-deficient cultures of Lactobacillus casei, Lb. delbrueckii and Kurthia zenkeri in medium 4, although the incidence of cells of abnormal length was decreased by the presence of the manganese ions. Cultures of the strains of staphylococci which grew in this medium contained an increased percentage of oval and giant cells at low magnesium concentrations. No change in the morphology of either Streptococcus pyogenes, or Strep. faecalis was observed when these organisms were cultivated in medium 4 containing $0-4$ p.p.m. of magnesium.

Gram-negative rods. No gross change in morphology was observed in cultures of Aerobacter aerogenes, Serratia marcescens and Pseudomonas aeruginosa under the conditions of the experiments of Fig. 4. A small percentage of short filaments was observed in cultures of $A$. cloacae, Escherichia coli var. acidilactici and Esch. coli commune (cf. Pl. 1, fig. 6) in either medium 1 or medium 2 (Table 2) containing low concentrations of magnesium (0.1-0.7 p.p.m.).

\section{Influence of the amino-acid composition of a magnesium-deficient medium on the morphology of Gram-positive cells}

The effect of different magnesium concentrations on the growth of $B$. mycoides in a simple chemically-defined medium (Koser \& Rettger, 1919), and in the same medium, but containing in addition, L-glutamic acid $(0.05 \% \mathrm{w} / \mathrm{v})$, L-tryptophan $(0.05 \% \mathrm{w} / \mathrm{v})$, L-cystine $(0.05 \% \mathrm{w} / \mathrm{v})$, L-arginine $(0.05 \% \mathrm{w} / \mathrm{v})$ and nicotinic acid $(0.001 \% \mathrm{w} / \mathrm{v})$, is shown in Fig. 5. In the simple medium (medium A), growth was a function of the magnesium concentration and reached a maximum at $c .40$ p.p.m., whereas in the medium supplemented with amino-acids and nicotinic acid (medium B), growth rapidly became independent of changes in magnesium concentration. Furthermore, normal cell division occurred in all cultures of $\boldsymbol{B}$. mycoides in medium $\mathbf{A}$ irrespective of the magnesium concentration, whereas in medium B filamentous cells were observed in cultures containing 5 p.p.m. of magnesium. It thus appeared possible that the synthetic processes, which, in medium $\mathbf{A}$, required magnesium for activation, were those concerned with the formation of the amino-acids present in medium B. In an attempt to determine whether magnesium was associated with the synthesis of one or all of the amino-acids (or nicotinic acid) each was added in turn to the basal medium (Koser \& Rettger, 1919) containing 5 p.p.m. of magnesium. Under these conditions it was to be expected that filamentous cells would be observed in the culture containing the amino-acids which, in the 
simple basal medium, was synthesized by a magnesium activated enzyme system. Each of the above substances stimulated the growth of $B$. mycoides, the greatest increase in growth occurring in the presence of glutamic acid (Table 5). Filamentous cells, however, were not observed in any of these cultures.

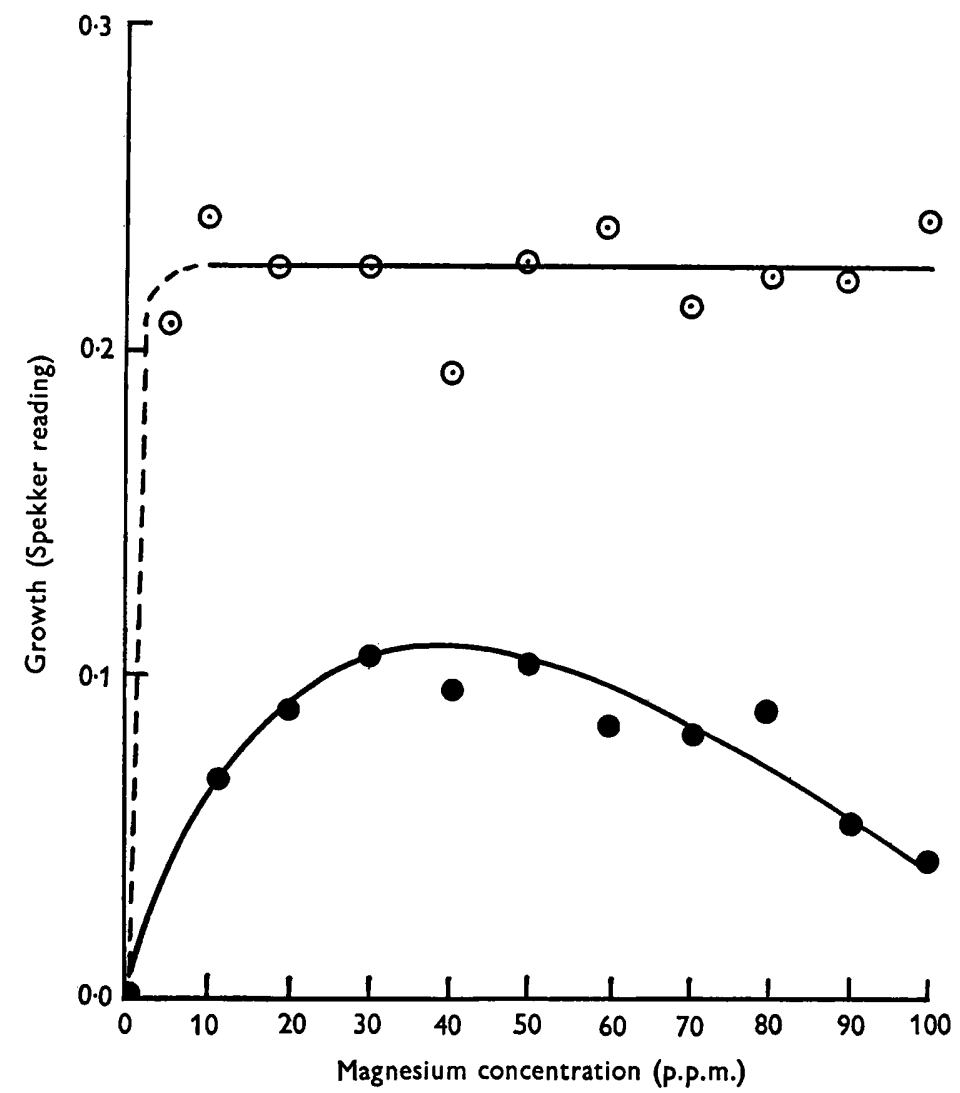

Fig. 5. The influence of magnesium on the growth of B. mycoides in Koser \& Rettger's (1919) medium (-O), and in the same medium supplemented by the addition of Lglutamic acid (0.05\%), L-tryptophan $(0.05 \%)$, L-cystine $(0.05 \%)$, L-arginine $(0.05 \%)$ and nicotinic acid $(0 \cdot 001 \%)(\odot-\odot)$.

In further experiments, the influence of various combinations of these amino-acids on the growth and cell division of $B$. mycoides was determined. Although filaments were formed in cultures containing only these four aminoacids, variable results were obtained when each was omitted in turn. Similar experiments, in which other combinations of amino-acids were studied, suggested that a certain minimal number of amino-acids (c. 4-6, according to the constitution of the individual amino-acids) was necessary before a deficiency of magnesium resulted in the formation of filamentous cells. In this connexion it is of interest to note that Stephens \& Hinshelwood (1949) showed that each addition of an amino-acid to a simple chemically-defined medium resulted in a 
progressive shortening of the mean generation time of $A$. aerogenes until, when some twenty amino-acids were present, the optimal mean generation time was attained.

Table 5. Effect of certain amino-acids and nicotinic acid on the growth of Bacillus mycoides in Koser \& Rettger's (1919) medium containing 5 p.p.m. of magnesium

(The table summarizes the results of four independent experiments.)

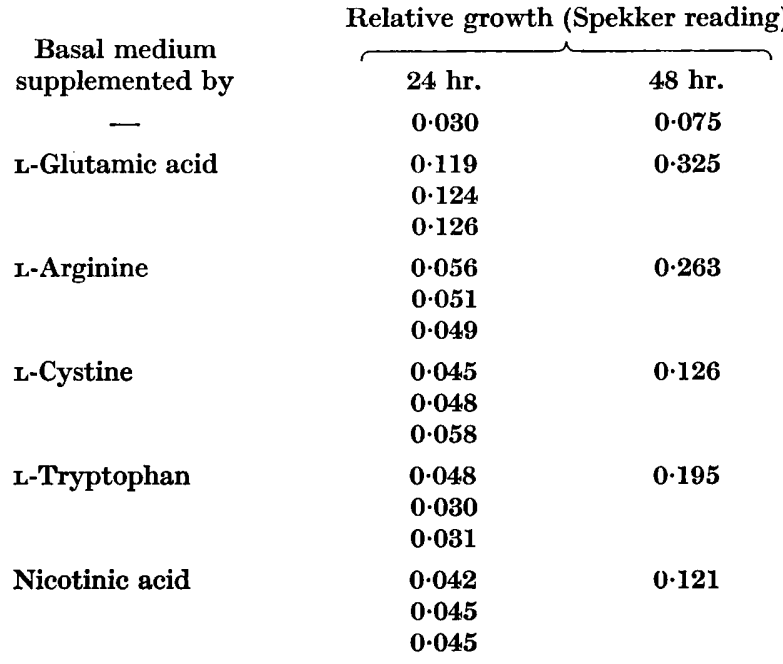

Furthermore, Gale (1949) has shown that either magnesium or manganese, or both, are involved in the assimilation of glutamic acid, and presumably certain other amino-acids, by Gram-positive cells (Staph. aureus). Since the co-ordination complex of 8-hydroxyquinoline with manganese is more stable than the corresponding complex with magnesium, it is apparent that a medium rendered biologically free from magnesium with 8 -hydroxyquinoline, must also be free from manganese. Thus, the assimilation of certain amino-acids from the chemically-defined media (other than medium 4) used in the present work must be activated by magnesium alone. In addition, there appears to be a certain parallel between the effect of magnesium on the growth of Gram-positive bacteria and its effect on the assimilation of amino-acids. For example, the assimilation of glutamic acid by Staph. aureus cells deficient in magnesium and manganese, initially increases rapidly with increases in the concentration of added magnesium, reaches a maximum at $c .10^{-5} \mathrm{M}(0 \cdot 26$ p.p.m. $)$ and then becomes independent of further increases in the magnesium concentration up to $10^{-2} \mathrm{M},=260$ p.p.m. (Gale, 1949, Fig. 5). Similarly, the growth of Grampositive bacteria increases rapidly with increasing magnesium concentration, reaches a maximum at 2-4 p.p.m. and then becomes independent of further increases in the magnesium concentration (Figs. 1, 2, Table 3). 


\section{DISCUSSION}

In a simple chemically-defined medium containing salts, glucose or glycerol, and a source of nitrogen, the magnesium requirements of Gram-positive organisms are about ten times as great as those of Gram-negative bacteria (Webb, 1949b). The results described in this paper also show that even in complex chemically-defined media, Gram-positive bacteria require more magnesium for maximum growth than do the Gram-negative species. In accordance with these facts, Gram-positive cells harvested from a culture medium of constant composition appear to contain greater amounts of magnesium than do Gram-negative organisms grown in the same medium (Webb, 1949a).

However, it is clear that much of the magnesium of Gram-positive bacteria (e.g. c. $\mathbf{7 0} \%$ in the case of $\mathbf{C l}$. welchii) is co-ordinated into the structure of the Gram complex (Henry \& Stacey, 1946) and is not available for the activation of essential systems of the cell. Thus it is probable that comparable concentrations of magnesium are required by both Gram-positive and Gram-negative organisms under normal conditions of growth for the activation of certain enzyme mechanisms such as those involved in the energy-yielding reactions, synthetic processes, assimilation and cell division. In simple chemically-defined media, where the synthetic activities of the cell are at a maximum, the concentration of magnesium necessary for the growth of a given organism is greater than that in a complex chemically-defined medium containing a range of essential metabolites. In media of the latter type, where the synthetic activities of the cell are decreased, low concentrations of magnesium produce little effect upon growth. In the case of the Gram-positive rods, however, these conditions are insufficient to maintain normal cell division and, in consequence, filamentous cells are formed.

Although much of the work recorded in this and previous papers has been carried out with strains of bacilli and clostridia, the fact that low concentrations of magnesium induce the formation of filaments in cultures of lactobacilli and Kurthia indicates that the effect of magnesium on cell division is not confined specifically to the Bacillaceae. At present it is not clear why a deficiency of magnesium in complex chemically-defined media inhibits the cell division only of the Gram-positive rods. It seems unlikely that Gram-positive and Gramnegative bacteria divide by different mechanisms, or that magnesium is essential for the cell division of the former, and not the latter. Gale and associates (e.g. Gale 1947, 1948) have shown that there is a marked difference between the amino-acid metabolism of Gram-positive and Gram-negative bacteria. It is possible, therefore, that the apparent lack of effect of magnesium deficiency on the morphology of Gram-negative rods is linked in some way with the metabolism of these cells in complex amino-acid mixtures.

Thanks are due to Prof. M. Stacey, F.R.S., and Dr H. B. Fell for their interest in this work, and to Messrs Z. Hybs, B.Sc., and G. F. Davenall for assistance with certain of the preliminary experiments which were carried out at the University of Birmingham. Grateful acknowledgement is made to Dr D. J. D. Nicholas for his kindness in making available the details of his 8-hydroxyquinoline method of purification prior to publication. 

Journal of General Microbiology, Vol. 5, No. 3
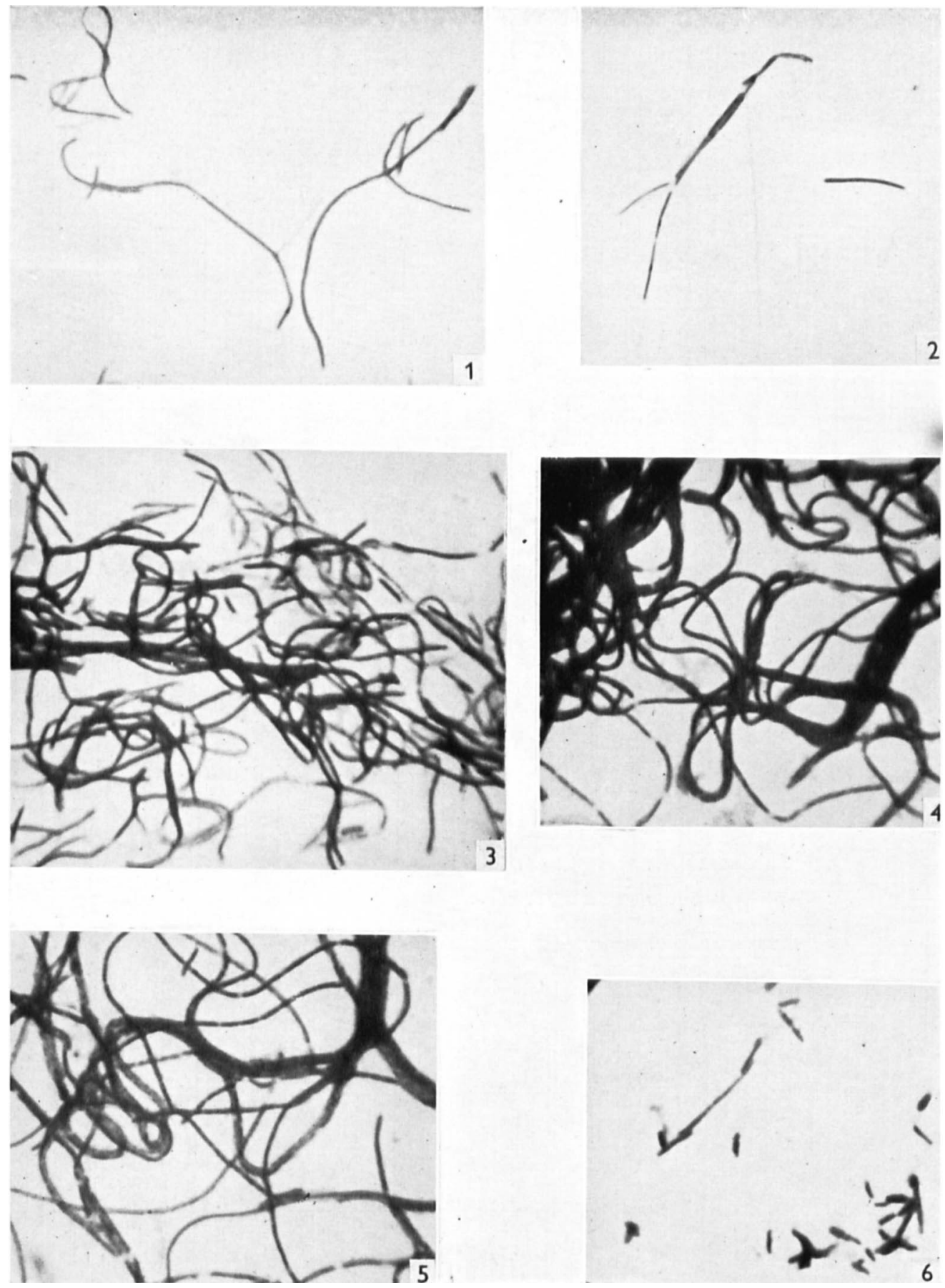

Figs. 1-6

M. Webb-Mg and bacterial growth in amino-acid media. Plate 1 


\section{REFERENCES}

Boyd, M. J., Logan, M. A. \& Tytell, A. A. (1948). The growth requirements of $\mathrm{Cl}$. perfringens (B.P. 6K). J. biol. Chem. 174, 1013.

Gale, E. F. (1947). Nitrogen metabolism. Ann. Rev. Microbiol. 1, 141.

Gale, E. F. (1948). ' Nitrogen metabolism of Gram-positive bacteria. Bull. Johns Hopk. Univ. 83, 119-75.

Gale, E. F. (1949). The assimilation of amino-acids by bacteria. 8. Trace metals in glutamic acid assimilation and their inactivation by 8 -hydroxyquinoline. J. gen. Microbiol. 3, 369.

Glinka-Tschernorutzky, E. (1933). Über den Stickstoffumsatz bei $B$. mycoidès. VI. Mitteilung. Über Ausnutzung verschiedener Stickstoffquellen durch den B. mycoides. Biochem. Z. 263, 144.

Heigener, H. (1935). Quoted by Porter, J. R. (1946). Bacterial Chemistry and Physiology, p. 681. New York: John Wiley and Sons Incor.

Henry, H. \& Stacey, M. (1946). Histochemistry of the Gram-staining reaction for micro-organisms. Proc. roy. Soc. B, 133, 391.

Koser, S. A. \& REtTger, L. F. (1919). Studies on bacterial nutrition. The utilization of nitrogenous compounds of definite chemical composition. J. infect. Dis. 24, 301.

Krueger, K. \& Peterson, W. H. (1945). The response of Lactobacillus casei and Streptococcus faecalis to Vitamin $B_{c}$ and thymine. J. biol. Chem. 158, 145.

Nicholas, D. J. D. (1951). The use of Aspergillus niger for the bioassay of $\mathrm{Mg}, \mathrm{Cu}$, Zn and Mo available in soils to crop plants. J. hort. Sci. (in the Press).

Shaffer, P. A. \& Hartman, A. F. (1920). The iodometric determination of copper and its use in sugar analysis. J. biol. Chem. 45, 365 .

Stephens, D. \& Hinshelwood, C. N. (1949). The conditions for optimal growth rate of Bact. lactis aerogenes. J. chem. Soc. p. 2516.

WARING, W. S. \& WERKMAN, C. H. (1942). Growth of bacteria in an iron free medium. Arch. Biochem. 1, 303.

WebB, M. (1948). The influence of magnesium on cell division. 1. The growth of Clostridium welchii in complex media deficient in magnesium. J. gen. Microbiol. 2, 275.

WEBB, M. (1949a). The influence of magnesium on cell division. 2. The effect of magnesium on the growth and cell division of various bacterial species in complex media. J. gen. Microbiol. 3, 410.

WEBB, M. (1949b). The influence of magnesium on cell division. 3. The effect of magnesium on the growth of bacteria in simple, chemically defined media. J. gen. Microbiol. 3, 418 .

Webs, M. (1951). The influence of magnesium on cell division. 4. The specificity of magnesium. J. gen. Microbiol. 5, 480.

\section{EXPLANATION OF PLATE}

(Magnification: figs. 1-5, $\times 1000$; fig. 6, $\times 1400$.)

Fig. 1. Filamentous forms of Bacillus subtilis, grown on Heigener's(1935) medium (medium 2, Table 2) containing 2 p.p.m. $\mathrm{Mg}^{++}$.

Fig. 2. B. mycoides after one subculture in Heigener's (1935) medium in the absence of magnesium (cf. Table 1).

Fig. 3. Clostridium welchii grown in medium 5 (Table 2) containing 5 p.p.m. $\mathbf{M g}^{++}$.

Figs. 4, 5. B. subtilis (fig. 4) and B. mycoides (fig. 5) grown in a complex amino-acid mixture (Glinka-Tschernorutzky, 1933) containing 2 p.p.m. $\mathrm{Mg}^{++}$.

Fig. 6. Escherichia coli commune grown in Heigener's (1935) medium containing 0.3 p.p.m. $\mathrm{Mg}^{++}$.

(Received 14 November 1950) 